https://doi.org/10.19195/0524-4544.329.26

\author{
ERYK KOSIŃSKI \\ ORCID: 0000-0002-2899-5228
}

Uniwersytet im. Adama Mickiewicza w Poznaniu erykk@amu.edu.pl

\title{
Rynek hurtowy energii elektrycznej jako instrument regulacji sektora elektroenergetycznego w Unii Europejskiej i na Ukrainie*
}

\begin{abstract}
Abstrakt: W publikacji dokonuje się analizy obowiązujących regulacji prawnych Unii Europejskiej oraz Ukrainy w zakresie organizacji i funkcjonowania rynku hurtowego energii elektrycznej. Obowiązująca unijna regulacja prawna pozwala na stwierdzenie, że realizowane są trzy główne cele regulacji: cele ekonomiczne (w tym w zakresie wspierania konkurencji), cele z zakresu zapewnienia bezpieczeństwa energetycznego oraz cele społeczne. W konsekwencji należy uznać rynek hurtowy energii elektrycznej za instrument regulacyjny. Ukraina przyjęła na siebie obowiązek wdrożenia przepisów unijnych w zakresie regulacji sektora energetycznego (acquis communautaire Wspólnoty Energetycznej). Ustawa Ukrainy z dnia 13 kwietnia 2017 roku o rynku energii elektrycznej w zakresie organizacji i funkcjonowania rynku hurtowego energii elektrycznej wdraża do ukraińskiego porządku prawnego podstawowe zasady trzeciego pakietu energetycznego. Wymagane jest jednak dalej idące dostosowanie prawa ukraińskiego do rozporządzenia 1227/2011 (tak zwany REMIT) oraz do przyjmowanych aktów czwartego pakietu energetycznego.
\end{abstract}

Słowa kluczowe: regulacja sektorowa, sektor elektroenergetyczny, rynek hurtowy energii.

* Niniejsze opracowanie stanowi rezultat prac autora w ramach projektu badawczego Narodowego Centrum Nauki nr 2016/21/B/HS5/00054, umowa nr UMO-2016/21/B/HS5/00054, pod tytułem „Regulacja sektora energetycznego w Unii Europejskiej oraz na Ukrainie. Porównanie celów i prawnych środków regulacji sektora energetycznego" (kierownik projektu: dr hab. E. Kosiński, prof. n. UAM). 


\section{Unijna regulacja rynku hurtowego energii elektrycznej}

W literaturze trafnie zwraca się uwagę, że jednym z kluczowych elementów w zakresie zapewnienia funkcjonowania zasad ekonomii oraz zagwarantowania bezpieczeństwa energetycznego jest wolny, konkurencyjny rynek energii — tak detaliczny, jak i hurtowy ${ }^{1}$.

Dyrektywa elektroenergetyczna pierwszego pakietu energetycznego, to jest dyrektywa 96/92/WE Parlamentu Europejskiego i Rady z dnia 19 grudnia 1996 roku dotycząca wspólnych zasad rynku wewnętrznego energii elektrycznej ${ }^{2}$, uznawała rynek hurtowy, obejmując definicją odbiorców (ang. customers) - także odbiorców hurtowych (hurtowników) energii elektrycznej oraz gazu ziemnego (art. 2 pkt 7 dyrektywy 96/92/WE). Dyrektywa definiowała nadto pojęcie odbiorców hurtowych (ang. wholesale customers), pozostawiając ich wprowadzenie oraz regulację prawną w danym sektorze do uznania państw członkowskich, jako osoby fizyczne bądź prawne, kupujące lub sprzedające energię elektryczną, niewykonujące działalności w zakresie przesyłu, wytwarzania bądź dystrybucji na zewnątrz lub wewnątrz systemu, do którego są przyłączeni (art. 2 pkt 8 dyrektywy 96/92/WE).

Drugi pakiet energetyczny, to jest dyrektywa Parlamentu Europejskiego i Rady 2003/54/WE z dnia 26 czerwca 2003 roku w sprawie wspólnych zasad wewnętrznego rynku energii elektrycznej i uchylająca dyrektywę 96/92/WE ${ }^{3}$, zdefiniowała odbiorców hurtowych jako ,każdą osobę fizyczną lub prawną, która kupuje energię elektryczną w celu odsprzedaży wewnątrz lub na zewnątrz systemu, w którym działa" (art. 2 pkt 8 dyrektywy 2003/54/WE). Drugi pakiet energetyczny nie pozostawiał już możliwości zapewnienia funkcjonowania rynków hurtowych energii uznaniu państw członkowskich. Wskazana dyrektywa w żaden szczegółowy sposób nie regulowała organizacji rynku hurtowego energii elektrycznej.

Określone zmiany w przedmiotowym zakresie przyniósł dopiero trzeci pakiet energetyczny. Dyrektywa Parlamentu Europejskiego i Rady 2009/72/WE z dnia 13 lipca 2009 roku dotycząca wspólnych zasad rynku wewnętrznego energii elektrycznej i uchylająca dyrektywę 2003/54/WE ${ }^{4}$ powierzyła krajowym organom regulacyjnym zadanie — monitorowanie poziomu przejrzystości funkcjonowania podmiotów na rynkach energii elektrycznej, w tym w zakresie określania cen hurtowych oraz poziomu i skuteczności otwarcia rynku i konkurencji na poziomie hurtowym i detalicznym, w tym na giełdach energii elektrycznej (pkt 61 pream-

1 Zob. obszerne rozważania w tym zakresie Security of Energy Supply in Europe. Natural Gas, Nuclear and Hydrogen, red. F. Levéque et al., Cheltenham-Northampton, MA 2010, passim, w szczególności J.M. Glachant, F. Levéque, P. Ranci, EU energy security of supply: conclusions, s. 295-301.

2 Dz.Urz. L 27, 30.01.1997, s. 20. Polskie wydanie specjalne: rozdział 12, t. 2, s. 3.

3 Dz.Urz. L 176, 15.07.2003, s. 37.

4 Dz.Urz. L 211, 14.08.2009, s. 55. 
buły, art. 37 ust. 1 pkt i-j dyrektywy 2009/72/WE). Dyrektywa nałożyła nadto na dostawców energii elektrycznej obowiązki w zakresie prowadzenia dokumentacji dotyczącej transakcji i umów zawieranych z odbiorcami hurtowymi (art. 40 ust. 1-7 dyrektywy 2009/72/WE).

Warunki do prawidłowego funkcjonowania rynku hurtowego energii elektrycznej na poziomie transgranicznym zapewnia rozporządzenie Parlamentu Europejskiego i Rady (WE) nr 714/2009 z dnia 13 lipca 2009 roku w sprawie warunków dostępu do sieci w odniesieniu do transgranicznej wymiany energii elektrycznej i uchylające rozporządzenie (WE) $\mathrm{nr} 1228 / 2003^{5}$. Zgodnie z art. 1 pkt $b$ rozporządzenie ma na celu ,ułatwienie powstania sprawnie funkcjonującego i przejrzystego rynku hurtowego charakteryzującego się wysokim poziomem bezpieczeństwa dostaw energii elektrycznej. Przewiduje ono mechanizmy harmonizacji zasad dotyczących transgranicznej wymiany energii elektrycznej”. Wskazane zasady dotyczą obowiązku operatorów systemów przesyłowych w zakresie promowania optymalnego zarządzania siecią i wspierania funkcjonowania giełd energii (art. 12 ust. 1 rozporządzenia 714/2009), obowiązku wytwórców energii elektrycznej w zakresie przechowywania i udostępniania danych godzinowych dotyczących wszystkich operacyjnych decyzji dyspozytorskich oraz postępowania podczas przetargów na giełdach energii, aukcjach połączeń wzajemnych, rynkach rezerwowych i rynkach pozagiełdowych (art. 15 ust. 6) oraz zakazu dyskryminacji w toku przydzielania zdolności przesyłowych $\mathrm{w}$ ramach zarządzania ograniczeniami (pkt 2.7 Załącznika I. Wytyczne w sprawie zarządzania i alokacji dostępnej zdolności przesyłowej połączeń wzajemnych między systemami krajowymi).

Z dniem 1 stycznia 2020 roku rozporządzenie 714/2009 zostało uchylone przez jeden $z$ aktów należących do czwartego pakietu energetycznego ${ }^{6}$ - rozporządzenie Parlamentu Europejskiego i Rady (UE) 2019/943 z dnia 5 czerwca 2019 roku w sprawie rynku wewnętrznego energii elektrycznej (art. $70 \mathrm{w}$ związku z art. 71 ust. 2 rozporządzenia 2019/943) ${ }^{7}$. Rozporządzenie 714/2009 w swej preambule wskazuje na doniosłość konkurencji na rynku hurtowym energii elektrycznej, co zagwarantowane zostało poprzez wdrożenie rynku wewnętrznego energii (pkt 2 preambuły). Ponadto podkreśla się znaczenie rynków krótkotermi-

5 Dz.Urz. L 211, 14.08.2009, s. 15.

${ }^{6}$ Na czwarty pakiet energetyczny (czy może lepiej — unię energetyczną) składają się między innymi: rozporządzenie Parlamentu Europejskiego i Rady (UE) 2018/1999 z dnia 11 grudnia 2018 roku w sprawie zarządzania unią energetyczną i działaniami w dziedzinie klimatu (Dz.Urz. L 328, 21.12.2018, s. 1); dyrektywa Parlamentu Europejskiego i Rady (UE) 2018/2001 z dnia 11 grudnia 2018 roku w sprawie promowania stosowania energii ze źródeł odnawialnych (Dz.Urz. UE L 328, 21.12.2018, s. 82); dyrektywa Parlamentu Europejskiego i Rady (UE) 2019/944 z dnia 5 czerwca 2019 roku w sprawie wspólnych zasad rynku wewnętrznego energii elektrycznej oraz zmieniająca dyrektywę 2012/27/UE (Dz.Urz. L 158, 14.06.2019, s. 125).

7 Dz.Urz. L 158, 14.06.2019, s. 54. 
nowych oraz mechanizmów ustalania cen w sposób odzwierciedlający niedobory mocy dla prawidłowego funkcjonowania rynku energii oraz zapewnienia bezpieczeństwa dostaw, przy krytyce stosowanych przez niektóre państwa członkowskie administracyjnych pułapów cenowych na rynku hurtowym (pkt 6, 24 preambuły; art. 1 pkt d rozporządzenia).

Celem rozporządzenia jest przeciwdziałanie stosowaniu przez państwa członkowskie tak zwanych mechanizmów zdolności wytwórczych (ang. capacity mechanism, franc. mécanisme de capacité), to jest tymczasowych mechanizmów mających zapewnić niezbędny poziom wystarczalności zasobów w przypadku nowych zdolności wytwórczych (art. 2 pkt 22; zob. pkt 4, 24, 43-50 preambuły).

Zabronione w sposób wyraźny zostaje stosowanie pułapów (limitów) hurtowych cen energii elektrycznej, zarówno maksymalnych, jak i minimalnych (art. 10 ust. 1). Zabronione jest podejmowanie przez operatorów systemów przesyłowych jakichkolwiek działań mających na celu zmianę poziomu cen hurtowych (art. 10 ust. 3). Nadzór nad przestrzeganiem przedmiotowych zakazów powierzony zostaje co do zasady krajowym organom regulacyjnym (art. 10 ust. 4-5). Rozporządzenie kompleksowo i szczegółowo reguluje nadto między innymi zasady funkcjonowania rynków energii elektrycznej (art. 3), rynków dnia następnego i dnia bieżącego i obrotu na nich (art. 7-8), rynków terminowych (ang. forward markets; art. 9) oraz odpowiedzialności za bilansowanie i rynku bilansującego (art. 5-6).

Ochrona konkurencji na rynku hurtowym energii oraz szczegółowa regulacja organizacji rynków hurtowych, w tym rejestracja uczestników rynku hurtowego energii elektrycznej i gazu ziemnego, jest przedmiotem regulacji rozporządzenia Parlamentu Europejskiego i Rady (UE) nr 1227/2011 z dnia 25 października 2011 roku w sprawie integralności i przejrzystości hurtowego rynku energii (tak zwany REMIT) ${ }^{8}$. Rozporządzenie ma za zadanie zapewnienie prawidłowego funkcjonowania rynków hurtowych, przede wszystkim ich uczciwości, przeciwdziałania nadużyciom, zagwarantowania funkcjonowania sił rynkowych (wolnej konkurencji, popytu i podaży; pkt 1-4, 11-17 preambuły do rozporządzenia). Rynek hurtowy rozumiany jest szeroko jako rynki regulowane, wielostronne platformy obrotu i transakcje zawierane na rynku pozagiełdowym oraz umowy dwustronne zawierane w sposób bezpośredni lub za pośrednictwem brokerów (pkt 5 preambuły).

Rozporządzenie wprowadza definicje pojęć: informacji wewnętrznej (art. 2 pkt 1), manipulacji na rynku (art. 2 pkt 2), próby manipulacji na rynku (art. 2 pkt 3). Rozporządzenie definiuje także pojęcie hurtowego rynku energii (ang. wholesale energy market; franc. marché de gros de l'énergie) ${ }^{9}$ elektrycznej jako każdy rynek w obrębie Unii, na którym prowadzony jest obrót produktami energetycznymi sprzedawanymi w obrocie hurtowym. Przez produkty energetyczne sprzedawane w obro-

8 Dz.Urz. L 326, 8.12.2011, s. 1.

${ }^{9}$ W polskiej wersji językowej rozporządzenia 1227/2011 nieprawidłowo używa się terminu „hurtowy rynek energii elektrycznej”, zawężając pojęcie do rynku wyłącznie energii elektrycznej. 
cie hurtowym (ang. wholesale energy products; franc. produits énergétiques de gros) z kolei rozumie się umowy i instrumenty pochodne, bez względu na miejsce i sposób prowadzonego nimi obrotu, których przedmiotem jest energia elektryczna i gaz ziemny (wytwarzanych, sprzedawanych bądź dostarczanych w Unii Europejskiej) oraz dostawy i przesył energii elektrycznej i gazu ziemnego (art. 2 pkt 4).

W celu zagwarantowania uczciwości obrotu energią elektryczną i gazem ziemnym oraz zapobieżenia manipulacjom na rynku hurtowym rozporządzenie 1227/2011 wprowadza zakaz wykorzystywania informacji wewnętrznych (nabywanie bądź zbywanie informacji, próby nabycia bądź sprzedaży informacji, ujawnianie informacji innej osobie, zalecanie bądź nakłanianie innej osoby do nabycia bądź zbycia produktów energetycznych na rynku hurtowym w oparciu o informację wewnętrzną; art. 3 ust. 1) ${ }^{10}$. Z drugiej strony na uczestników rynku hurtowego nałożony zostaje obowiązek podawania właściwych, istotnych dla funkcjonowania rynku informacji do wiadomości publicznej (art. 4 ust. 1-7). Bezwzględny zakaz dokonywania bądź usiłowania dokonania manipulacji na rynku zawarty jest $\mathrm{w}$ art. 5 rozporządzenia. Monitoring rynku hurtowego energii powierzony został Agencji Unii Europejskiej do spraw Współpracy Organów Regulacji Energetyki ${ }^{11}$ (art. 7-8). Uczestnicy rynku zobowiązani są do przedkładania Agencji informacji na temat transakcji i zleceń na hurtowych rynkach energii, których przedmiotem są produkty energetyczne (art. 8 ust. 1) ${ }^{12}$. Uczestnicy rynku, zobowiązani do informowania Agencji o wymienionych transakcjach i zleceniach, mają nadto obowiązek rejestrowania się w krajowym rejestrze uczestników rynku hurtowego prowadzonym przez krajowy organ regulacyjny dla sektora energetycznego (art. 9 ust. 1-5). Nadzór nad przestrzeganiem zakazów i obowiązków wprowadzonych przez rozporządzenie spoczywa na krajowych organach regulacyjnych (art. 13-14).

W zakresie realizacji celów społecznych regulacji sektorowej rynek hurtowy energii elektrycznej powiązany zostaje $z$ dobrobytem gospodarstw domowych przez dyrektywę elektroenergetyczną czwartego pakietu energetycznego (unia energetyczna), to jest dyrektywę Parlamentu Europejskiego i Rady (UE) 2019/944 z dnia 5 czerwca 2019 roku w sprawie wspólnych zasad rynku wewnętrznego energii elektrycznej oraz zmieniającą dyrektywę 2012/27/UE ${ }^{13}$. Wprowadzane

${ }^{10}$ Zakres podmiotowy zakazu uregulowany jest w art. 3 ust. 2 i 5 . Wyłączenia podmiotowe i przedmiotowe spod zakazu uregulowane są w art. 3 ust. 3, 4 i 6.

11 Następczyni Agencji ds. Współpracy Organów Regulacji Energetyki. Zob. rozporządzenie Parlamentu Europejskiego i Rady (UE) 2019/942 z dnia 5 czerwca 2019 roku ustanawiające Agencję Unii Europejskiej do spraw Współpracy Organów Regulacji Energetyki (Dz.Urz. L 168, 14.06.2019, s. 22). Rozporządzenie 2019/942 weszło w życie z dniem 4 lipca 2019 roku.

12 Zob. zakres przedmiotowy tego obowiązku, zasady formalne i terminy w rozporządzeniu wykonawczym Komisji (UE) nr 1348/2014 z dnia 17 grudnia 2014 roku w sprawie przekazywania danych wdrażające art. 8 ust. 2 i 6 rozporządzenia Parlamentu Europejskiego i Rady (UE) nr 1227/2011 w sprawie integralności i przejrzystości hurtowego rynku energii (Dz.U. L 363, 18.12.2014, s. 121).

13 Dz.Urz. L 158, 14.06.2019, s. 125. Dyrektywa ta uchyla dyrektywę 2009/72/WE z dniem 1 stycznia 2021 roku (art. 72 dyrektywy 2019/944). 
przez dyrektywę 2019/944/UE umowy z cenami dynamicznymi energii elektrycznej (zdefiniowanej przez art. 1 pkt 15 dyrektywy ${ }^{14}$ ) jako formy aktywnego uczestnictwa w rynku energii wprowadzają powiązanie pomiędzy konsumentami i cenami energii płaconymi przez nich $\mathrm{z}$ rynkiem hurtowym i cenami występującymi na tym rynku (pkt 37-38 preambuły do dyrektywy). Odbiorcy mają prawo do zawarcia umowy na dostawę energii elektrycznej z cenami dynamicznymi energii elektrycznej (art. 11 ust. 1-4 dyrektywy). Umowa tego typu może być zawierana z wieloma dostawcami (mającymi co najmniej 200 tysięcy odbiorców końcowych; art. 11 ust. 1). Państwa członkowskie mają czas na wdrożenie wymienionych regulacji do dnia 31 grudnia 2020 roku (art. 71 ust. 1 pierwszy akapit).

\section{Reforma regulacji sektora energetycznego Ukrainy w latach 2015-2017}

Jeszcze za prezydentury Wiktora Janukowycza z dniem 1 lutego 2011 roku Ukraina formalnie przystąpiła do Wspólnoty Energetycznej (Energy Community) ${ }^{15}$, przyjmując na siebie szereg obowiązków, w tym w zakresie implementacji unijnych przepisów i zasad w zakresie energetyki (acquis communautaire Wspólnoty Energetycznej). W dniu 21 marca 2014 roku podpisany został w Brukseli Układ stowarzyszeniowy pomiędzy Unią Europejską i jej państwami członkowskimi a Ukrainą ${ }^{16}$. Sam Układ stowarzyszeniowy, niezależnie od Traktatu ustanawiającego Wspólnotę Energetyczną, nakłada na strony obowiązek kontynuowania i pogłębiania współpracy w obszarze energetyki, w tym w zakresie bezpieczeństwa energetycznego oraz zbliżenia regulacji sektorowej Ukrainy do regulacji unijnej (art. 337 ust. 1 układu).

W następstwie przyjętych przez Ukrainę zobowiązań w zakresie dostosowania krajowego porządku prawnego do regulacji unijnych przyjęta została ustawa Ukrainy nr 329-VIII z dnia 9 kwietnia 2015 roku o rynku gazu ziemnego (Закон

14 „Umowa z ceną dynamiczną energii elektrycznej oznacza umowę na dostawy energii elektrycznej między dostawcą a odbiorcą końcowym, odzwierciedlającą wahania cen na rynkach transakcji natychmiastowych, w tym na rynkach dnia następnego i dnia bieżącego, w odstępach co najmniej równych częstotliwości rozliczeń na rynku".

15 Traktat ustanawiający Wspólnotę Energetyczną z dnia 25 października 2005 roku (Treaty establishing the Energy Community) Dz.Urz. UE L 198, 20.07.2006, s. 18; polska wersja językowa zob. http://ec.europa.eu/transparency/ regdoc/rep/ 1/2005/PL/1-2005-435-PL-F1-2.Pdf (dostęp: 25.08.2019). Traktat ratyfikowany został przez Ukrainę w dniu 15 grudnia 2010 roku. Zob. https:// www.energy-community.org/implementation/Ukraine.html (dostęp: 15.04.2019).

16 Układ został ratyfikowany ustawą przez Radę Najwyższą Ukrainy w dniu 16 września 2014 roku, tego samego dnia podpisaną przez prezydenta P. Poroszenkę. 
України від 9 квітня 2015 року № 329-VIII «Про ринок природного газу») $)^{17}$. W zakresie regulacji sektora elektroenergetycznego przyjęta została ustawa Ukrainy nr 2019-VIII z dnia 13 kwietnia 2017 roku o rynku energii elektrycznej (Закон України від 13 квітня 2017 року № 2019-VIII «Про ринок електроенергії») $)^{18}$. Zakres działania i kompetencje organu regulacyjnego dla sektora energetycznego uregulowała uchwalona w dniu 22 września 2016 roku ustawa Ukrainy nr 1540VIII o Komisji Narodowej do spraw Regulacji Państwowej w Zakresie Energetyki i Usług Komunalnych (Закон України від 22 вересня 2016 року № 1540-VIII «Про Національну Комісію що здійснює державне регулювання у сферах енергетики та комунальних послуг» $)^{19}$.

\section{Prawne reguły organizacji rynku hurtowego energii elektrycznej na Ukrainie}

Ustawa Ukrainy nr 2019-VIII z dnia 13 kwietnia 2017 roku o rynku energii elektrycznej definiuje zasadnicze pojęcia rynku hurtowego - trader (przedsiębiorca dokonujący kupna energii elektrycznej wyłącznie w celu jej odsprzedaży, z wyłączeniem sprzedaży na podstawie umowy na dostawę energii elektrycznej na rzecz odbiorcy; art. 1 ust. 1 pkt 92); rynek dnia bieżącego (art. 1 ust. 1 pkt 14); rynek energii elektrycznej (art. 1 ust. 1 pkt 74); rynek dnia następnego (art. 1 ust. 1 pkt 75); aukcja energii elektrycznej na rynku dnia bieżącego (art. 1 ust. 1 pkt 90) oraz aukcja energii elektrycznej na rynku dnia następnego (art. 1 ust. 1 pkt 90) ${ }^{20}$. Rynek hurtowy energii elektrycznej rozpoczął funkcjonowanie $z$ dniem 1 lipca 2019 roku (ust. 1 rozdziału XVII. Przepisy końcowe i przejściowe) ${ }^{21}$.

17 WWR (Widimosti Wierchownej Rady; ukr. Відомості Верховної Ради України; pol. Biuletyn Rady Najwyższej Ukrainy) 2015, nr 27, s. 234 ze zm. Ustawa weszła w życie z dniem 1 października 2015 roku.

18 WWR 2017, nr 27-28, s. 312 ze zm. Ustawa weszła w życie z dniem 11 czerwca 2017 roku i w zasadniczej swej części wdraża do ukraińskiego porządku prawnego unijne trzeci pakiet energetyczny, to jest przede wszystkim dyrektywę Parlamentu Europejskiego i Rady 2009/72/WE z dnia 13 lipca 2009 roku dotyczącą wspólnych zasad rynku wewnętrznego energii elektrycznej i uchylającą dyrektywę 2003/54/WE (Dz.Urz. UE L 211, 14.8.2009, s. 55).

19 WWR 2016, Nr 51, s. 833 ze zm.

20 Zob. przekład ustawy Ukrainy nr 2019-VIII z dnia 13 kwietnia 2017 roku o rynku energii elektrycznej na język polski, [w:] Prawo energetyczne Ukrainy. Wybór źródeł, red. E. Kosiński, Poznań 2018, s. 299 n.

${ }^{21}$ Pomimo działań podejmowanych przez prezydenta Wołodymira Zełenskiego, mających na celu opóźnienie rozpoczęcia funkcjonowania rynku hurtowego energii elektrycznej o rok. Zob. Zelenskij prizval Radu otsročit' vvedenie novogo rynka èlektroènergii do 1 iûlâ 2020 goda (Зеленский призвал Раду отсрочить введение нового рынка электроэнергии до 1 июля 2020 года), 102. UA, 10.06.2019 (dostęp: 27.08.2019). 
Rynek hurtowy zorganizowany jest na zasadzie umów dwustronnych (art. 66 ust. 1-4 ustawy o rynku energii elektrycznej) ${ }^{22}$. Ponadto transakcje dokonywane mogą być na rynku dnia bieżącego i rynku dnia następnego (definiowanych w art. 1 ust. 1 pkt 14 i 75 ustawy o rynku energii elektrycznej, określanych wraz z rynkiem bilansującym jako zorganizowany segment rynku energii elektrycznej, art. 1 ust. 1 pkt 58 ustawy) w trybie aukcji na rynku dnia bieżącego i na rynku dnia następnego. Warunki uczestnictwa i tryb dokonywania transakcji na rynkach dnia bieżącego i dnia następnego określa art. 67 ust. 1-9 ustawy o rynku energii elektrycznej. Szczegółowe zasady funkcjonowania rynku hurtowego określają zasady rynku energii elektrycznej (zatwierdzone zarządzeniem Komisji Narodowej do spraw Regulacji Państwowej w Zakresie Energetyki i Usług Komunalnych nr 307 z dnia 14 marca 2018 roku ${ }^{23}$ oraz zasady rynku dnia następnego i dnia bieżącego (zatwierdzone zarządzeniem Komisji Narodowej ds. Regulacji Państwowej w Zakresie Energetyki i Usług Komunalnych nr 308 z dnia 14 marca 2018 roku) ${ }^{24}$.

Ustawa o rynku energii elektrycznej wprowadza szczególną koncesjonowaną działalność traderską, polegającą na zakupie energii elektrycznej w celu jej odsprzedaży (art. 54 ust. 1 ustawy). Podjęcie i wykonywanie działalności traderskiej wymaga uzyskania koncesji przyznawanej przez organ regulacyjny (art. 8 ust. 3 i art. 55 ust. 2 ustawy ${ }^{25}$. Działalność ta $z$ zasady prowadzona jest na zorganizowanych segmentach rynku energii elektrycznej (rynki hurtowe; art. 54 ust. 2 ustawy). Prawa i obowiązki traderów reguluje art. 55 ust. 1-2 ustawy.

Obrót giełdowy energią elektryczną odbywa się na utworzonej w 2010 roku Giełdzie Towarowej „Ukraińska Giełda Energetyczna” (Товарна біржа „Українська енергетична біржа”, ТБ „УЕБ” $)^{26}$. Aukcje elektroniczne na rynku dnia bieżącego i rynku dnia następnego wdrażane były w maju i czerwcu 2019 roku $^{27}$.

22 Rynek hurtowy energii typu OTC (ang. over the counter).

23 Постанова № 307 Про затвердження Правил ринку. Uriadowyj Kurier nr 117 z 22.06. 2018 r., https://zakon5.rada.gov.ua/laws/show/v0307874-18 (dostęp: 30.04.2019).

24 Постанова № 308 Про затвердження Правил ринку «на добу наперед» та внутрішньодобового ринку. Uriadowyj Kurier nr 118 z 23.06.2018 r., http://zakon5.rada.gov.ua/laws/show/ v0308874-18 (dostęp: 30.04.2019).

25 Art. 1 ust. 1 pkt 92 definiuje pojęcie tradera jako przedsiębiorcę dokonującego „kupna energii elektrycznej wyłącznie w celu jej odsprzedaży, z wyłączeniem sprzedaży na podstawie umowy na dostawę energii elektrycznej na rzecz odbiorcy".

${ }^{26}$ Ukraińska Giełda Energetyczna utworzona została na podstawie ustawy Ukrainy nr 1956 XII z dnia 10 grudnia 1991 roku o giełdzie towarowej (Закон України від 10 грудня 1991 року № 1956XII „Про товарну біржу”, WWR 1992, Nr 10, s. 139) i przez pierwsze lata działalności dokonywano na niej obrotu biopaliwami stałymi (biomasą) oraz węglem (pierwsze aukcje elektroniczne odbyły się w październiku 2011 roku). Do chwili obecnej na giełdzie skupia się $80 \%$ obrotu biomasą. Por. https:// www.ua-region.com/37027819 (dostęp: 20.08.2019).

27 Testowany był system elektroniczny i oprogramowanie komputerowe. Zob. https://www. ueex.com.ua/eng/ auctions/electricenergy/testing/ (dostęp: 27.05.2019). 


\section{Wnioski}

Analiza przedmiotowych regulacji prawnych prowadzi do wniosku, że instrument regulacyjny w postaci prawnych ram oraz zasad organizacji i funkcjonowania rynku hurtowego energii realizuje większość z celów regulacyjnych — zarówno cele ekonomiczne (efektywność, wydajność, sprawność funkcjonowania, równoważenie popytu i podaży, wspieranie konkurencji rynkowej), cele w zakresie zapewnienia bezpieczeństwa energetycznego, a także cele społeczne (ochrona dobrobytu konsumentów, szczególnie odbiorców ubogich) ${ }^{28}$.

Regulacja unijna przechodzi metamorfozę. Krystalizujący się czwarty pakiet energetyczny (klimatyczno-energetyczny czy unia energetyczna) wprowadza zmiany $\mathrm{w}$ regulacji sektora elektroenergetycznego, $\mathrm{w}$ tym $\mathrm{w}$ zakresie organizacji rynku hurtowego energii.

Ukraina w 2017 roku przyjęła nową ustawę regulującą sektor elektroenergetyczny. Przepisy te zapewniają ramy prawne funkcjonowania rynku hurtowego energii elektrycznej i wdrażają do ukraińskiego porządku prawnego unijne regulacje trzeciego pakietu energetycznego. Brak jednak pełnego wdrożenia szczegółowych unijnych rozwiązań, jak tych z rozporządzenia 1227/2011 (tak zwany REMIT). Co więcej, prawo ukraińskie będzie wymagało dostosowania do przyjmowanych aktów czwartego pakietu energetycznego. Wreszcie, pomimo wprowadzenia nowej ustawy, zwraca się uwagę na liczne ograniczenia regulacyjne zarówno na rynku pozagiełdowym, jak i dnia bieżącego, dnia następnego oraz bilansującym energii elektrycznej (ceny minimalne i maksymalne). Duża część energii energetycznej produkowanej na Ukrainie sprzedawana jest $\mathrm{w}$ ramach obowiązków użyteczności publicznej jednemu nabywcy (tak jak pod rządem poprzednio obowiązujących przepisów) ${ }^{29}$.

\section{Bibliografia}

Kosiński E., Regulacja sektora energetycznego w Unii Europejskiej oraz na Ukrainie. Cele i prawne środki regulacji sektora energetycznego, Poznań 2019.

Kosiński E., Regulacja sektorowa - stałość czy zmienność pojęcia?, [w:] Prawne instrumenty oddziaływania na gospodarkę, red. A. Powałowski, Warszawa 2016.

28 Zob. na temat celów realizowanych przez regulację sektorową E. Kosiński, Regulacja sektorowa - stałość czy zmienność pojęcia?, [w:] Prawne instrumenty oddziaływania na gospodarkę, red. A. Powałowski, Warszawa 2016, s. 119-120; nadto idem, Regulacja sektora energetycznego w Unii Europejskiej oraz na Ukrainie. Cele i prawne środki regulacji sektora energetycznego, Poznań 2019, passim.

29 Zob. Ukrainian wholesale electricity market opening: 53\% of electricity generation traded on the free market, but reforms may be at risk, 1.09.2019, https://www.energy-community.org/news/ Energy-Community-News/2019/09/05.html (dostęp: 8.09.2019). 
„,Naftogaz” načnet torgi gazom na Ukrainskoj ènergetičeskoj birže, https://biz.censor.net.ua/news/3129447/ naftogaz_nachnet_torgi_gazom_na_ukrainskoyi_energetiches koyi_birje (dostęp: 28.08.2019).

Prawo energetyczne Ukrainy. Wybór źródet, red. E. Kosiński, Poznań 2018.

Security of Energy Supply in Europe. Natural Gas, Nuclear and Hydrogen, red. F. Levéque, J.M. Glachant, J. Barquín, Ch. von Hirschhausen, F. Holz, W.J. Nuttall, Cheltenham-Northampton, MA 2010 .

Potencial biržovoï torgivli gazom v Ukraïni pereviŝue 10 mlrd dolariv SŠA, 104.UA, 8.12.2017, https://104. ua/ua/news/id/potencial-birzhovoji-torgivli-gazom-v-ukrajini-per-26484 (dostęp: 27.08.2019).

Ukrainian wholesale electricity market opening: $53 \%$ of electricity generation traded on the free market, but reforms may be at risk, 5.09.2019, https://www.energy-community.org/news/Energy-Community-News/2019/09/05.html (dostęp: 8.09.2019).

Vidbulisâ perši torgi prirodnim gazom z točkoû peredači v pidzemnih shovišah, 16.11.2017, https:// www.ukrinform.ua/rubric-economy/2345531-vidbulisa-persi-torgi-prirodnim-gazom-z-tockou-peredaci-v-pidzemnih-shovisah.html (dostęp: 12.05.2019).

Zelenskij prizval Radu otsročit' vvedenie novogo rynka èlektroènergii do 1 iûlâ 2020 goda, 102.UA, 10.06.2019 (dostęp: 27.08.2019).

https://www.ueex.com.ua/eng/auctions-calendar/natural-gas/ (dostęp: 27.08.2019).

https://www.ua-region.com/37027819 (dostęp: 27.08.2019).

\section{The wholesale electric energy market as a regulatory instrument of the electric energy sector in the European Union and Ukraine}

Summary

In this article, there is an analysis of valid European Union and Ukraine legal regulations in the area of the wholesale energy market's organisation and functioning provided. The valid EU regulation allows us to draw the conclusion that there are 3 major goals accomplished by the energy sector regulations: economic goals (i.a. procompetitive support), energy security, and social goals. Consequently, the wholesale energy market can be regarded as a regulatory instrument. Ukraine assumed the obligation to implement EU legislation in the field of energy sector regulation (Energy Community acquis communautaire). The Act of Ukraine of 13th April 2017 in electric energy market implements the fundamental principles of the third energy package in the area of organisation and functioning of the wholesale electric energy market. It is required, however, to provide for a further implementation of EU regulation 1227/2011 (REMIT) and of the fourth energy package.

Keywords: sector-specific regulation; electric energy sector of economy; wholesale energy market. 